\title{
PENGARUH PEMBERIAN EKSTRAK GULMA Azolla pinnata DAN LAMA PERENDAMAN AIR KELAPA TERHADAP PERTUMBUHAN DAN HASIL KACANG TANAH
}

\section{The Effect of Azolla pinnata Weed Extract and Long Soaking of Coconut Water on Peanut Growth and Yield}

\author{
Muhammad Rezky Dwiputra Pulungan ${ }^{a}$, Oktavianus Lumban Tobing ${ }^{b^{*}}$, Yanyan Mulyaningsih ${ }^{\mathrm{b}}$ \\ aprogram Studi Agroteknologi, Fakultas Pertania, Universitas Djuanda

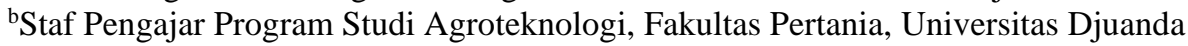 \\ Jalan Tol Ciawi, No. 1 Kotak Pos 35 Ciawi-Bogor, 16720 \\ *Email korespondensi: oktavianus@unida.ac.id
}

Diterima 21 Oktober 2020/Disetujui 27 April 2021

\begin{abstract}
ABSTRAK
Tujuan penelitian untuk memahami pengaruh pemberian ekstrak Azolla pinnata dan lama perendaman benih pada air kelapa terhadap pertumbuhan dan hasil tanaman kacang tanah. Percobaan menggunakan rancangan acak lengkap (RAL) faktorial. Dosis Azolla pinnata terdiri atas empat taraf: 0\%, 1\%, 1.5\%, dan 2\% masa media tanam $(\mathrm{mmt})$. Lama perendaman benih dengan air kelapa terdiri atas empat taraf yaitu direndam selama 0 jam, 6 jam, 12 jam, dan 24 jam. Dosis pemberian Azolla pinnata pada media tanam dan lama perendaman benih dalam air kelapa memberikan pengaruh positif pada pertumbuhan tinggi tanaman, jumlah daun, luas daun, bobot segar dan kering tajuk, bobot segar akar, jumlah polong, persentase polong isi, dan jumlah bintil akar. Azolla pinnata dapat menjadi pupuk alternatif, dan air kelapa dapat berfungsi sebagai zat pengatur tumbuh alami.
\end{abstract}

Kata kunci: gulma air, produksi kacang tanah, ZPT alami

\section{ABSTRACT}

The aim of this research was to understand the effect of giving Azolla pinnata extract and the duration of soaking the seeds in coconut water on the growth and yield of peanut plants. The experiment used a factorial completely randomized design (CRD). The dosage of Azolla pinnata consists of four levels: $0 \%, 1 \%, 1.5 \%$, and $2 \%$ mass of growing media (mmt). The duration of soaking the seeds with coconut water consists of four levels, namely soaking for 0 hours, 6 hours, 12 hours, and 24 hours. The dose of giving Azolla pinnata on the planting media and the duration 'of soaking the seeds in coconut water had a positive effect on plant height growth, number of leaves, leaf area, shoot fresh and dry weight, root fresh weight, number of pods, percentage of filled pods, and number of root nodules. Azolla pinnata can be an alternative fertilizer, and coconut water can function as a natural growth regulator.

Keywords: natural PGRs, peanut production, water weed

\section{PENDAHULUAN}

Kacang tanah merupakan salah satu komoditas agribisnis yang mempunyai nilai ekonomi tinggi, karena selain dapat dikonsumsi langsung juga dapat dijadikan bahan baku olahan pabrik. Peningkatan produksi kacang tanah dapat dilakukan antara lain melalui pemberian ekstrak gulma Azolla piñata dan air kelapa. Produk olahan dari kacang tanah antara lain selai, kue kering, bumbu cilok, bumbu balado, dan pecel sayur.
Kandungan gizi yang terdapat dalam $100 \mathrm{~g}$ kacang tanah yaitu karbohidrat $(21 \mathrm{~g})$, air $(4,26 \mathrm{~g})$, protein $(25 \mathrm{~g})$, gula (0 g), serat (9 g), lemak (48 g), vitamin A (0 $\mathrm{g})$, Vitamin $\mathrm{C}(0 \mathrm{~g})$, vitamin $\mathrm{D}(0 \mathrm{~g})$, vitamin $\mathrm{E}(6,6 \mathrm{mg})$, vitamin $\mathrm{K}(1,9 \mathrm{ug})$. Manfaat kacang tanah bagi kesehatan, yaitu membantu mencegah risiko diabetes, mencegah pembentukan batu empedu, menurunkan resiko stroke, menjaga kesehatan jantung, menjaga kesehatan kulit, mencegah kanker perut, mencegah depresi (Dickson 2021). 
Pertumbuhan dan hasil kacang tanah dapat ditingkatkan antara lain dengan cara pemberian ekstrak Azolla piñata pada media tanam dan perendaman biji kacang tanah dengan air kelapa. Azolla dapat menyediakan unsur nitrogen bagi tanaman, karena Cyanobacteria terdapat pada Azolla sehingga dapat melakukan simbiosis mutualisme yang dikenal dengan Anabaena azollae. N2 bebas dapat difiksasi oleh Anabaena azollae sehingga $\mathrm{N}$ tersedia bagi tanaman (Sudjana 2014).

Air kelapa mengandung zat pengatur tumbuh kinetin, zeatin, auksin, juga vitamin, mineral, dan sumber karbon yang berguna untuk multiplikasi tunas in vitro. Zat pengatur tumbuh merupakan senyawa organik bukan nutrisi yang dalam konsentrasi rendah $(<1 \mathrm{mM})$ mendorong, menghambat, atau secara kualitatif mengubah pertumbuhan dan perkembangan tanaman. Pertumbuhan, perkembangan, dan pergerakan tumbuhan dikendalikan beberapa golongan zat yang secara umum dikenal sebagai hormon tumbuhan atau fitohormon (Anjarsari 2008). Kandungan sitokinin dan auksin pada air kelapa muda lebih tinggi dibandingkan air kelapa tua. Di samping itu hara makro $\mathrm{N}, \mathrm{P}$, dan $\mathrm{K}$, dan hara mikro yang terdapat pada air kelapa muda berpotensi sebagai sumber karbon dalam bentuk sukrosa (Kristina dan Syahid 2012).

Azolla dan air kelapa mudah diperoleh karena merupakan limbah hasil pertanian, juga harganya relatif murah dibandingkan penggunaan zat pengatur tumbuh sintetik buatan pabrik. Oleh sebab itu dilakukan penelitian ini untuk mengetahui seberapa besar pengaruh dari pemberian azolla dan air kelapa terhadap pertumbuhan dan hasil tanaman kacang tanah.

\section{MATERI DAN METODE}

Penelitian ini dilaksanakan pada bulan Januari 2019 sampai bulan April 2019 di lahan percobaan Asrama IPB
Sukasari, Jalan Siliwangi no. 17, Bogor Timur, Kota Bogor.

Rancangan penelitian yang digunakan adalah rancangan acak lengkap (RAL) faktorial yang diulang 3 kali. Faktor pertama yang diuji adalah dosis pembenaman Azolla pinnata pada media tanam kacang tanah (massa media tanam/mmt) yang mengacu pada Danuarti (2017). Taraf faktor pertama adalah $\mathrm{A} 0=$ $0 \% \mathrm{mmt}(0 \mathrm{~g}$ per polybag $), \mathrm{A} 1=1 \% \mathrm{mmt}$ (200 g per polybag), A2 $=1,5 \% \mathrm{mmt}(300$ g per polybag), $\mathrm{A} 3=2 \% \mathrm{mmt}$ (400 g per polybag). Faktor kedua yang diuji adalah lama waktu perendaman benih kacang tanah dalam air kelapa yang berpedoman pada Ratnawati et al. (2013). Air kelapa yang digunakan pada penelitian ini adalah air kelapa muda, karena menurut hasil penelitian terdahulu kelapa muda memiliki kandungan ZPT maupun nutrisi lebih baik daripada air kelapa tua. Taraf faktor kedua adalah $\mathrm{B} 0=$ tanpa perendaman, $\mathrm{B} 1=6 \mathrm{jam}$, $\mathrm{B} 2=12 \mathrm{jam}$, dan B3 = 24 jam. Dengan demikian, terdapat 16 kombinasi perlakuan yang diulang 3 kali, sehingga diperoleh 48 satuan percobaan. Setiap satuan percobaan terdiri atas 3 tanaman, sehingga terdapat 144 amatan tanaman.

Alat yang digunakan pada penilitian ini adalah cangkul, meteran, penggaris, polybag, ember, gembor, dan sekop mini. Bahan yang digunakan adalah benih kacang tanah, air kelapa, A. pinnata, tanah, kompos, pupuk urea, SP36, $\mathrm{KCl}$ dan dolomite.

Pembenaman $A$. pinnata pada media tanam dilakukan 14 hari sebelum benih kacang tanah ditanam. Hal tersebut dilakukan agar $A$. pinnata terdekomposisi dengan baik, sehingga pengaruhnya terhadap pertumbuhan kacang tanah optimum (Daniarti 2017). Sebelum diaplikasikan, A. pinnata dicuci bersih terlebih dahulu dan dikeringkan. Pengeringan dilakukan untuk mempercepat proses dekomposisi dan pelepasan unsur hara dapat lebih dini. Hal ini sesuai dengan pernyataan Gunawan dan Kartina (2012) bahwa pembenaman $A$. pinnata kering ke 
dalam tanah lebih baik untuk mempercepat proses dekomposisi dan pelepasan unsur hara, sehingga fungsi tanaman sebagai pupuk hayati dapat memberikan hasil terbaik. Setelah kering, A. pinnata dimasukkan ke dalam media tanam sesuai dosis perlakuan yang telah ditetapkan. Proses pengeringan sebelum $A$. pinnata diaplikasikan dalam media tanam polibeg dilakukan 14 hari sebelum tanam bersamaan dengan pengolahan tanah.

Peubah yang diamati pada penelitian ini adalah tinggi tanaman $(\mathrm{cm})$, jumlah daun, luas daun $(\mathrm{cm})$, bobot segar tajuk (g), bobot kering tajuk (g), bobot segar akar (g), bobot kering akar (g), jumlah polong, bobot polong (g), presentase polong hampa, dan presentase polong isi. Data yang diperoleh kemudian dianalisis menggunakan analisis ragam dan diuji lanjut dengan DMRT (Duncan's Multiple Range Test) pada taraf $5 \%$ jika pengaruh perlakuan nyata.

\section{HASIL DAN PEMBAHASAN}

Hasil

Pengaruh pemberian Azolla pinnata dan lama perendaman air kelapa terhadap peubah tinggi tanaman tercermin dari hasil uji nilai rata-rata tinggi tanaman yang ditampilkan pada Tabel 1 dan Tabel 2.

Tabel 1. Tinggi kacang tanah umur 2-8 MST

\begin{tabular}{lcccc}
\hline \multirow{2}{*}{ Perlakuan } & \multicolumn{4}{c}{ Umur Tanaman $(\mathrm{cm})$} \\
\cline { 2 - 5 } & $2 \mathrm{MST}$ & \multicolumn{4}{c}{$4 \mathrm{MST}$} & $6 \mathrm{MST}$ & $8 \mathrm{MST}$ \\
\hline & \multicolumn{4}{c}{ Azolla pinnata } \\
$0 \% \mathrm{mmt}$ & $10,44^{\mathrm{a}}$ & $17,29^{\mathrm{a}}$ & $25,11^{\mathrm{a}}$ & $32,03^{\mathrm{a}}$ \\
$1 \% \mathrm{mmt}$ & $10,80^{\mathrm{b}}$ & $17,82^{\mathrm{b}}$ & $25,48^{\mathrm{ab}}$ & $32,54^{\mathrm{b}}$ \\
$1,5 \% \mathrm{mmt}$ & $11,18^{\mathrm{c}}$ & $18,18^{\mathrm{c}}$ & $26,04^{\mathrm{b}}$ & $33,27^{\mathrm{c}}$ \\
$2 \% \mathrm{mmt}$ & $11,75^{\mathrm{d}}$ & $18,59^{\mathrm{d}}$ & $26,76^{\mathrm{c}}$ & $33,38^{\mathrm{c}}$ \\
& Perendaman air kelapa & & \\
Tidak direndam & $10,80^{\mathrm{a}}$ & $17,76^{\mathrm{a}}$ & $25,69^{\mathrm{a}}$ & $31,80^{\mathrm{a}}$ \\
6 jam & $10,85^{\mathrm{a}}$ & $17,88^{\mathrm{ab}}$ & $25,49^{\mathrm{a}}$ & $32,68^{\mathrm{b}}$ \\
12 jam & $10,89^{\mathrm{a}}$ & $18,08^{\mathrm{b}}$ & $25,64^{\mathrm{a}}$ & $33,33^{\mathrm{c}}$ \\
24 jam & $11,63^{\mathrm{b}}$ & $18,17^{\mathrm{b}}$ & $26,56^{\mathrm{b}}$ & $33,41^{\mathrm{c}}$ \\
\hline
\end{tabular}

Keterangan: Nilai rata-rata pada kolom yang sama diikuti huruf yang sama tidak berbeda nyata menurut uji DMRT pada taraf $5 \%$.

Tinggi tanaman kacang tanah pada 2-8 MST yang diberi perlakuan Azolla pinnata secara umum lebih tinggi dari yang tidak diberi perlakuan Azzola pinnata. Tinggi tanaman kacang tanah cenderung meningkat sejalan dengan peningkatan dosis Azzola pinnata yang diberikan. Tanaman kacang tanah yang diberi perlakuan perendaman selama 24 jam lebih tinggi dari tanaman tanpa perlakuan perendaman sejak umur 2 MST, tanaman yang diberi perlakuan perendaman selama 12 lebih tinggi dari tanaman tanpa perlakuan perendaman pada umur 4 MST dan 8 MST, sedangkan tanaman yang diberi perlakuan perendaman selama 6 jam lebih tinggi dari tanaman tanpa perlakuan perendaman pada umur 8 MST. Tinggi tanaman kacang tanah cenderung meningkat sejalan dengan peningkatan lama perendaman (Tabel 1).

Padadosis Azolla pinnata sebesar $0 \% \mathrm{mmt}$ dan $2 \% \mathrm{mmt}$, tanaman kacang tanah yang diberi perlakuan perendaman 6 jam dan 24 jam lebih tinggi dibandingkan tanaman yang tidak diberi perlakuan perendaman. Pada dosis Azolla pinnata sebesar $1 \% \mathrm{mmt}$ dan $1,5 \% \mathrm{mmt}$, tinggi tanaman kacang tanah yang diberi perlakuan perendaman lebih tinggi dibandingkan yang tidak diberi perlakuan perendaman (Tabel 2). 
Tabel 2. Tinggi kacang tanah pada 8 MST pada berbagai dosis Azolla pinnata dan lama perendaman pada air kelapa

\begin{tabular}{lllll}
\hline \multicolumn{1}{c}{ Perlakuan } & \multicolumn{4}{c}{ Azolla pinnata } \\
\hline \multicolumn{1}{c}{ Perendaman air kelapa } & \multicolumn{1}{c}{$0 \% \mathrm{mmt}$} & \multicolumn{1}{c}{$1 \% \mathrm{mmt}$} & \multicolumn{1}{c}{$1,5 \% \mathrm{mmt}$} & $2 \% \mathrm{mmt}$ \\
\hline Tidak direndam & $30.60^{\mathrm{a}}$ & $31.53^{\mathrm{b}}$ & $32.10^{\mathrm{c}}$ & $32.20^{\mathrm{cd}}$ \\
6 jam & $32.57^{\mathrm{cde}}$ & $32.60^{\mathrm{cdef}}$ & $32.80^{\mathrm{ef}}$ & $32.83^{\mathrm{ef}}$ \\
12 jam & $32.87^{\mathrm{ab}}$ & $33.00^{\mathrm{efg}}$ & $33.03^{\mathrm{efg}}$ & $33.20^{\mathrm{bc}}$ \\
24 jam & $33.53^{\mathrm{gh}}$ & $33.53^{\mathrm{gh}}$ & $33.93^{\mathrm{hi}}$ & $34.53^{\mathrm{i}}$ \\
\hline
\end{tabular}

Keterangan: Nilai rata-rata pada kolom yang sama diikuti huruf yang sama tidak berbeda nyata menurut uji DMRT pada taraf $5 \%$.

Pengaruh pemberian Azolla pinnata dan lama perendaman air kelapa terhadap peubah jumlah daun dan luas daun tercermin berdasarkan hasil uji rata-rata jumlah daun dan luas daun yang ditampilkan pada Tabel 3.

Pada 2-6 MST jumlah daun tanaman kacang tanah yang diberi perlakuan Azolla pinnata lebih banyak dibandingkan jumlah daun tanaman kacang tanah yang tidak diberi perlakuan Azolla pinnata. Ada kecenderungan bahwa semakin tinggi dosis Azolla pinnata yang diberikan jumlah daun tanaman kacang tanah yang dihasilkan semakin banyak. Pada 2-6 MST jumlah daun tanaman kacang tanah yang diberi perlakuan perendaman dengan air kelapa lebih banyak dibandingkan jumlah daun tanaman kacang tanah yang tidak diberi perlakuan perendaman. Ada kecenderungan bahwa semakin lama perlakuan perendaman dengan air kelapa yang diberikan jumlah daun tanaman kacang tanah yang dihasilkan semakin banyak (Tabel 3).

Tabel 3. Jumlah daun kacang tanah umur 2-6 MST dan luas daun umur 4-8 MST

\begin{tabular}{lcccccc}
\hline \multirow{2}{*}{ Perlakuan } & \multicolumn{3}{c}{ Jumlah daun } & \multicolumn{3}{c}{ Luas daun $(\mathrm{cm})$} \\
\cline { 2 - 6 } & 2 MST & 4 MST & 6 MST & 4 MST & 6 MST & 8 MST \\
\hline \multirow{5}{*}{$0 \% \mathrm{mmt}$} & $18,25^{\mathrm{a}}$ & $23,92^{\mathrm{a}}$ & $34,33^{\mathrm{a}}$ & $767,17^{\mathrm{a}}$ & $1022,83^{\mathrm{a}}$ & $1281,67^{\mathrm{a}}$ \\
$1 \% \mathrm{mmt}$ & $19,00^{\mathrm{b}}$ & $24,83^{\mathrm{b}}$ & $35,50^{\mathrm{b}}$ & $771,67^{\mathrm{b}}$ & $1027,33^{\mathrm{b}}$ & $1285,83^{\mathrm{b}}$ \\
$1,5 \% \mathrm{mmt}$ & $19,25^{\mathrm{b}}$ & $25,92^{\mathrm{c}}$ & $36,08^{\mathrm{b}}$ & $773,33^{\mathrm{bc}}$ & $1030,66^{\mathrm{c}}$ & $1289,00^{\mathrm{bc}}$ \\
$2 \% \mathrm{mmt}$ & $20,17^{\mathrm{c}}$ & $26,75^{\mathrm{d}}$ & $36,92^{\mathrm{c}}$ & $776,17^{\mathrm{c}}$ & $1032,66^{\mathrm{c}}$ & $1292,83^{\mathrm{c}}$ \\
\multicolumn{5}{c}{ Perendaman air kelapa } \\
Tidak direndam & $17,67^{\mathrm{a}}$ & $24,08^{\mathrm{a}}$ & $33,50^{\mathrm{a}}$ & $767,67^{\mathrm{a}}$ & $1024,50^{\mathrm{a}}$ & $1284,17^{\mathrm{a}}$ \\
6 jam & $18,92^{\mathrm{b}}$ & $25,17^{\mathrm{b}}$ & $34,00^{\mathrm{a}}$ & $771,67^{\mathrm{b}}$ & $1026,17^{\mathrm{ab}}$ & $1285,33^{\mathrm{a}}$ \\
12 jam & $19,58^{\mathrm{b}}$ & $25,58^{\mathrm{b}}$ & $37,17^{\mathrm{b}}$ & $772,83^{\mathrm{bc}}$ & $1028,83^{\mathrm{b}}$ & $1287,67^{\mathrm{a}}$ \\
24 jam & $20,50^{\mathrm{c}}$ & $26,58^{\mathrm{c}}$ & $38,17^{\mathrm{b}}$ & $776,17^{\mathrm{c}}$ & $1034,00^{\mathrm{c}}$ & $1292,17^{\mathrm{b}}$ \\
\hline
\end{tabular}

Keterangan: Nilai rata-rata pada kolom yang sama diikuti huruf yang sama tidak berbeda nyata menurut uji DMRT pada taraf $5 \%$.

Daun tanaman kacang tanah yang diberi perlakuan perendaman dengan air kelapa selama 24 jam lebih luas dibandingkan daun tanaman kacang tanah yang tidak diberi perlakuan perendaman pada semua umur. Daun tanaman kacang tanah yang diberi perlakuan perendaman dengan air kelapa selama 12 jam lebih luas dari daun tanaman kacang tanah yang tidak diberi perlakuan perendaman pada umur 4 MST dan 6 MST. Daun tanaman kacang tanah yang diberi perlakuan perendaman dengan air kelapa selama 6 jam lebih luas dari daun tanaman kacang tanah yang tidak 
diberi perlakuan perendaman hanya pada umur 4 MST (Tabel 3).

Indikasi adanya pengaruh pemberian Azolla pinnata dan lama perendaman air kelapa terhadap peubah bobot segar dan kering tajuk serta bobot segar dan kering akar terlihat pada Tabel 4.

Tabel 4. Bobot segar dan kering tajuk serta bobot segar dan kering akar kacang tanah

\begin{tabular}{llclc}
\hline \multirow{2}{*}{ Perlakuan } & \multicolumn{2}{c}{ Bobot Tajuk Tanaman $(\mathrm{g})$} & \multicolumn{2}{c}{ Bobot Akar Tanaman $(\mathrm{g})$} \\
\cline { 2 - 5 } & Bobot Segar & Bobot Kering & Bobot Segar & Bobot Kering \\
\hline \multirow{3}{*}{$0 \% \mathrm{mmt}$} & $41,83^{\mathrm{a}}$ & Azolla pinnata & \\
$1 \% \mathrm{mmt}$ & $42,75^{\mathrm{b}}$ & $20,58^{\mathrm{a}}$ & $13,44^{\mathrm{a}}$ & 3,64 \\
$1,5 \% \mathrm{mmt}$ & $43,00^{\mathrm{b}}$ & $22,08^{\mathrm{bc}}$ & $13,78^{\mathrm{ab}}$ & 3,69 \\
$2 \% \mathrm{mmt}$ & $43,42^{\mathrm{b}}$ & $22,75^{\mathrm{c}}$ & $14,15^{\mathrm{b}}$ & 3,73 \\
& & $14,93^{\mathrm{c}}$ & 3,78 \\
Tidak direndam & $42,58^{\mathrm{a}}$ & $21,00^{\mathrm{a}}$ & $12,90^{\mathrm{a}}$ & 3,64 \\
6 jam & $42,17^{\mathrm{a}}$ & $21,25^{\mathrm{ab}}$ & $13,26^{\mathrm{a}}$ & 3,69 \\
12 jam & $42,25^{\mathrm{a}}$ & $21,92^{\mathrm{bc}}$ & $14,48^{\mathrm{b}}$ & 3,74 \\
24 jam & $44,00^{\mathrm{b}}$ & $22,67^{\mathrm{c}}$ & $15,67^{\mathrm{c}}$ & 3,76 \\
\hline
\end{tabular}

Keterangan: Nilai rata-rata pada kolom yang sama diikuti huruf yang sama tidak berbeda nyata menurut uji DMRT pada taraf $5 \%$.

Bobot segar tajuk tanaman kacang tanah yang diberi perlakuan Azolla pinnata lebih berat dibandingkan bobot segar tajuk tanaman kacang tanah yang tidak diberi perlakuan Azolla pinnata, tetapi di antara dosis Azolla pinnata tidak ada perbedaan bobot segar tajuk. Perlakuan perendaman dengan air kelapa selama 24 jam mampu meningkatkan bobot segar tajuk, sedangkan perlakuan perendaman dengan air kelapa selama 6 dan 12 jam belum mampu meningkatkan bobot segar tajuk (Tabel 4).

Bobot kering tajuk tanaman kacang tanah yang diberi perlakuan Azolla pinnata lebih berat dibandingkan bobot kering tajuk tanaman kacang tanah yang tidak diberi perlakuan Azolla pinnata. Ada kecenderungan bahwa semakin tinggi dosis Azolla pinnata yang diberikan maka bobot kering tajuk tanaman yang dihasilkan semakin berat. Perlakuan perendaman dengan air kelapa selama 12 jam dan 24 jam mampu meningkatkan bobot kering tajuk, sedangkan perlakuan perendaman dengan air kelapa selama 6 jam belum mampu meningkatkan bobot kering tajuk. Ada kecenderungan bahwa semakin lama perlakuan perendaman dengan air kelapa yang diberikan semakin berat bobot kering tajuk tanaman kacang tanah yang dihasilkan (Tabel 4).

Perlakuan pemberian Azolla pinnata dengan dosis $1,5 \% \mathrm{mmt}$ dan $2 \%$ mmt mampu meningkatkan bobot segar akar tanaman kacang tanah, namun pemberian Azolla pinnata pada semua dosis yang dicoba tidak mampu meningkatkan bobot kering akar. Ada kecenderungan bahwa semakin tinggi dosis Azolla pinnata yang diberikan maka bobot segar agar yang dihasilkan semakin berat. Perlakuan perendaman dengan air kelapa selama 6 jam belum mampu meningkatkan bobot segar akar, sedangkan perlakuan perendaman selama 12 jam dan 24 jam mampu meningkatkan bobot segar akar. Perbedaan lama perendaman dengan air kelapa tidak menghasilkan perbedaan bobot kering akar (Tabel 4).

Adanya pengaruh pemberian Azolla pinnata dan lama perendaman air kelapa terhadap peubah jumlah, bobot polong, presentase polong isi, presentase polong hampa dan jumlah bintil dapat diketahui berdasarkan hasil uji rata-rata yang disajikan pada Tabel 5. 
Jumlah polong tanaman kacang tanah yang mendapat perlakuan Azolla pinnata $1,5 \% \mathrm{mmt}$ dan $12 \% \mathrm{mmt}$ lebih banyak dibandingkan jumlah polong kacang tanah yang tidak mendapat perlakuan Azolla pinnata. Perlakuan perendaman dengan air kelapa selama 12 jam dan 24 jam memberikan jumlah polong lebih banyak dibandingkan perlakuan tanpa perendaman. Sementara itu bobot polong kacang tanah tidak terpengaruh oleh perlakuan Azolla pinnata maupun perendaman dengan air kelapa, bobot polong pada semua perlakuan tidak berbeda nyata (Tabel 5).

Tabel 5 Jumlah dan bobot polong, presentase polong isi dan hampa, serta jumlah bintil kacang tanah

\begin{tabular}{|c|c|c|c|c|c|}
\hline \multirow{2}{*}{ Perlakuan } & \multicolumn{4}{|c|}{ Polong tanaman } & \multirow[t]{2}{*}{ Jumlah Bintil } \\
\hline & Jumlah & Bobot $(\mathrm{g})$ & $\%$ polong isi & \% polong hampa & \\
\hline \multicolumn{6}{|c|}{ Azolla pinnata } \\
\hline $0 \% \mathrm{mmt}$ & $4,83^{\mathrm{a}}$ & 17,42 & $85,35^{\mathrm{a}}$ & $14,65^{b}$ & $6,92^{\mathrm{a}}$ \\
\hline $1 \% \mathrm{mmt}$ & $5,17^{\mathrm{ab}}$ & 17,49 & $85,26^{\mathrm{a}}$ & $14,74^{\mathrm{b}}$ & $7,58^{\mathrm{ab}}$ \\
\hline $1,5 \% \mathrm{mmt}$ & $5,58^{\mathrm{bc}}$ & 17,54 & $86,19^{\mathrm{ab}}$ & $14,39^{\mathrm{b}}$ & $7,75^{\mathrm{b}}$ \\
\hline $2 \% \mathrm{mmt}$ & $5,75^{\mathrm{c}}$ & 17,62 & $87,70^{\mathrm{b}}$ & $12,30^{\mathrm{a}}$ & $8,33^{\mathrm{b}}$ \\
\hline \multicolumn{6}{|c|}{ Perendaman air kelapa } \\
\hline Tidak direndam & $4,75^{\mathrm{a}}$ & 17,55 & $83,37^{\mathrm{a}}$ & $12,53^{\mathrm{a}}$ & $6,58^{\mathrm{a}}$ \\
\hline 6 jam & $5,08^{\mathrm{ab}}$ & 17,52 & $86,06^{\mathrm{b}}$ & $12,98^{\mathrm{a}}$ & $7,50^{\mathrm{b}}$ \\
\hline $12 \mathrm{jam}$ & $5,58^{\mathrm{bc}}$ & 17,49 & $87,03^{\mathrm{bc}}$ & $13,94^{\mathrm{a}}$ & $8,17^{\mathrm{bc}}$ \\
\hline 24 jam & $5,91^{\mathrm{c}}$ & 17,51 & $88,05^{\mathrm{c}}$ & $16,63^{\mathrm{b}}$ & $8,33^{\mathrm{c}}$ \\
\hline
\end{tabular}

Keterangan: Nilai rata-rata pada kolom yang sama diikuti huruf yang sama tidak berbeda nyata menurut uji DMRT pada taraf $5 \%$.

Perlakuan Azolla pinnata pada dosis $2 \%$ mmt mampu meningkatkan persentase polong isi dan menurunkan persentase polong hampa, sedangkan perlakuan Azolla pinnata pada taraf yang lain belum memberikan hasil yang berbeda dengan hasil tanpa perlakuan Azolla pinnata. Perlakuan Azolla pinnata dengan dosis $1,5 \%$ mmt dan $2 \%$ mmt juga mampu meningkatkan jumlah bintil akar. Perlakuan lama perendaman dengan air kelapa selama 24 jam mampu meningkatkan persentase polong isi dan menurunkan persentase polong hampa. Perlakuan perendaman benih dengan air kelapa selama 6, 12, dan 24 jam juga mampu meningkatkan jumlah bintil akar (Tabel 5).

\section{Pembahasan}

Pemberian Azolla pinnata pada media dan perendaman benih dengan air kelapa berpengaruh pada tinggi tanaman, tanaman kacang tanah yang mendapat perlakuan Azolla pinnata maupun yang mendapat perlakuan perendaman benih dengan air kelapa lebih tinggi dibandingkan tanaman kacang tanah pada perlakuan kontrol. Hal ini sejalan dengan penelitian Daniarti (2017) yang menyatakan bahwa Azolla pinnata mengandung nitrogen yang berpengaruh terhadap organ vegetatif utama tanaman, pemberian Azolla pinnata pada berbagai dosis memberikan pengaruh yang berbeda pada pertumbuhan tanaman. Pemberian pupuk nitrogen ke dalam tanah akan meningkatkan pertumbuhan vegetatif tanaman, semakin tinggi pupuk nitrogen yang diberikan sampai suatu batas tertentu semakin tinggi pula variabel pertumbuhan tanaman, dalam hal ini terutama pada tinggi tanaman (Sutedjo dan Kartasapoetra 1990). Kandungan kinetin yang terdapat di dalam air kelapa dapat meningkatkan aktivitas fotosintesis sehingga memacu pertumbuhan dan meningkatkan produksi tanaman (Ariyanti et al. 2019).

Pertumbuhan jumlah dan luas daun tanaman yang diberi perlakuan Azolla pinnata dan air kelapa lebih cepat daripada tanpa pemberian Azolla pinnata dan air 
kelapa. Hasil penelitian Mayura et al. (2016) air kelapa mengandung $\mathrm{Ca}$ dan vitamin yang digunakan untuk merangsang pertumbuhan daun.

Bobot segar dan kering tajuk tanaman dengan pemberian Azolla pinnata dan air kelapa lebih besar daripada tanpa pemberian Azolla pinnata dan air kelapa. Menurut Suryati et al. (2015 Sudjana) pemberian Azolla pinnata sebagai pupuk organik pada suatu tanaman mampu mensuplai unsur hara yang diserap tanaman terutama unsur N, P dan K. Hasil penelitian Rover (2006) menyatakan bahwa pemberian air kelapa muda pada tanaman kedelai berpengaruh terhadap diameter batang, jumlah cabang primer, umur berbunga, jumlah polong pertanaman, jumlah polong bernas pertanaman, dan berat kering 100 biji, hal itu disebabkan air kelapa selain mengandung mineral juga mengandung hormon sitokinin, fosfor, dan kinetin yang berfungsi mempergiat pembelahan sel dan mempunyai pengaruh terhadap perkecambahan dan pertumbuhan di antaranya pertumbuhan tunas dan akar. Dengan demikian air kelapa baik untuk pertumbuhan bobot segar dan kering tajuk tanaman.

Bobot segar akar tanaman dengan pemberian Azolla pinnata dan air kelapa lebih besar dibandingkan tanpa pemberian Azolla pinnata dan air kelapa. Dengan pemberian Azolla pinnata dan air kelapa pertumbuhan akar lebih baik daripada tanpa pemberian Azolla pinnata dan air kelapa.

Azolla pinnata merupakan penyedia nitrogen, kalium, dan fosfor yang lebih banyak dibandingkan pupuk kandang sapi, pupuk kandang ayam, dan pupuk kascing, yang bermanfaat dalam hal pembentukan polong sehingga dapat mempengaruhi produksi polong yang dihasilkan. Pemberian bahan organik dapat menyediakan unsur nitrogen, kalium, kalsium dan ketersediaan unsur fosfor yang mudah larut dalam tanah, yang cukup diperlukan tanaman kacang tanah untuk perkembangan polongnya. Hal ini didukung dengan hasil penelitian yang dilakukan Indria (2005) bahwa jumlah polong tanaman dipengaruhi oleh pemberian Azolla pinnata dan air kelapa.

Persentase polong isi, persentase polong hampa, dan jumlah bintil akar tanaman dengan pemberian Azolla pinnata dan air kelapa lebih baik daripada tanpa pemberian Azolla pinnata dan air kelapa. Hasil penelitian ini sesuai dengan pendapat yang mengemukakan bahwa suatu tanaman akan tumbuh dan mencapai tingkat produksi tinggi apabila unsur hara yang dibutuhkan tanaman dalam keadaan cukup dan berimbang dalam tanah. Meningkatnya unsur hara nitrogen dalam tanah akan meningkatkan unsur hara yang lainnya juga, sehingga ketersediaan karbohidrat akan meningkat yang dapat digunakan untuk memproduksi bobot biji menjadi lebih berat (Lubis et al. 2013).

Azolla pinnata berfungsi sebagai penyumbang unsur hara makro, terutama nitrogen yang terakumulasi pada massa media tanaman yang telah mengalami dekomposisi lanjut, selain unsur nitrogen juga terdapat unsur makro dan mikro. Unsur Nitrogen lebih banyak terdapat daripada unsur makro lainnya pada media massa Azolla pinnata dikarenakan tanaman ini dapat bersimbiosis mutualisme dengan Anabaena azollae, yaitu ganggang hijau biru yang mempunyai enzim nitogenase yang dapat merubah nitrogen hasil fiksasi menjadi amonia, dan amonia diangkut oleh Azolla pinnata kemudian dirubah menjadi asam amino dan digunakan untuk fotosintesis.

Air kelapa berperan sebagai penghasil zat pengatur tumbuh alami, umumnya dari golongan auksin, sitokinin, dan geberellin. Auksin dapat menstimulir kompenen dari pertumbuhan tanaman terutama pada bagian ujung apikal titik tumbuh dan akar, sedangkan sitokinin menstimulir pertumbuhan tunas samping. Giberelin berperan dalam pemanjangan sel, antara lain pada pertambahan tinggi tanaman..

Total unsur nitrogen yang dapat difiksasi melalui simbiosis Azolla pinnata- 
Anabaena azollae cukup tinggi. Penambatan nitrogen $\left(\mathrm{N}_{2}\right)$ sebesar 7,2 - 7,8 $\mathrm{mg} \mathrm{N}_{2}$ per gram berat/kering (Kuncarawati et al. 2005). Azolla sangat efektif digunakan sebagai pupuk organik untuk mempertahankan kesuburan tanah, setiap hektar sawah memerlukan azolla sejumlah 20 ton dalam keadaan kering. Bila azolla diberikan setiap musim tanam, maka tingkat pemakaian pupuk buatan akan semakin berkurang. Hal ini dikarenakan pada pemberian pertama seperempat bagian unsur yang dikandung azolla langsung dimanfaatkan oleh tanah. Seperempat bagian ini setara dengan $65 \mathrm{~kg}$ pupuk urea. Pada musim tanam ke-2 dan ke-3, azolla mensubsitusikan seperempat sampai sepertiga dosis pemupukan. Penggunaan azolla sebagai pupuk, selain dalam bentuk seg ar, baik juga dalam bentuk kering dan kompos (Fitria 2015). Air kelapa selain mengandung ZPT, yakni: auksin, giberelin, dan sitokinin, juga mengandung nutrisi, yang paling tinggi kadarnya adalah kalium. Kalium berperan pada proses pertumbuhan tanaman karena dapat meningkatkan laju fotosintesis, sehingga terjadi peningkatan hasil fotosintat yang diperlukan tanaman dalam proses pertumbuhan, seperti tinggi tanaman, luas daun, dan bobot segar dan kering tajuk (Wijaya 2019).

\section{KESIMPULAN}

Perlakuan pemberian Azolla pinnata terutama pada dosis $2 \%$ massa media tanam dan perendaman benih kacang tanah dalam air kelapa terutama selama 24 jam berhasil meningkatkan pertumbuhan dan hasil kacang tanah. Peningkatan pertumbuhan dan hasil kacang tanah meliputi peubah tinggi tanaman, jumlah daun, luas daun, bobot segar dan kering tajuk, bobot segar akar, jumlah polong, persentase polong isi, dan jumlah bintil akar.

\section{DAFTAR PUSTAKA}

Ariyanti M, Rosniawaty S, Permana MR. 2019. Respons pertumbuhan tanaman kelapa belum menghasilkan terhadap pemberian air kelapa dan asam humat. Kultivasi UNPAD. 18(3):996-1003.

Daniarti H, Nurmilawati M, Sulistiono. 2017. Pengaruh dosis dan waktu aplikasi Azolla sp. terhadap pertumbuhan tanaman kacang tanah (Arachis hypogaea (L.) Merr.). Jurnal Biologi dan Pembelajarannya. 4(1):19-25

Anjarsari IRD. 2008. Peranan dan Fungsi Fitohormon bagi Pertumbuhan Tanaman.

http://pustaka.unpad.ac.id/wpcontent/uploads/2009/06/makalah_ fitohormon.pdf.

Dickson. 2021. Kandungan Gizi Kacang Tanah dan Manfaat Kacang Tanah bagi Kesehatan.

Fitria E. 2015. Azolla, Tanaman Paku Air yang Menguntungkan Padi Sawah. nad.litbang.pertanian.go.id/ind/inde x.php/info-teknologi/776-azollatanaman-paku-air-yangmenguntungkan-padi-sawah.

Gunawan I, Kartina R. 2012. Substitusi kebutuhan nitrogen tanaman padi sawah oleh tumbuhan air azolla (Azolla pinnata). Jurnal Penelitian Pertanian Terapan. 12(3): 175-180

Indria. 2005. Pengaruh Dosis dan Waktu aplikasi Azolla pinnata Terhadap Pertumbuhan dan Produktivitas Tanaman (Arachis hypogaea (L.) Merr.) [Skripsi]. Kediri [ID] : PGRI Kediri.

Kristina NV, Syahid SF. 2012. Pengaruh air kelapa terhadap multiplikasi tunas in vitro, produksi rimpang, dan kandungan xanthorrhizol temulawak di lapangan. Jurnal Littri 18(3):125-134

Kuncarawati IL, Husen S, Rukhiyat M. 2005. Aplikasi teknologi pupuk organik azolla pada budidaya padi 
sawah di Desa Mandesan Kecamatan Selopuro Kabupaten Blitar. Dedikasi. 3:10-16.

Lubis AI, Jumini, Syafruddin. 2013. Pertumbuhan dan hasil tanaman kacang tanah (Arachis hypogea L.) akibat pengaruh dosis pupuk $\mathrm{N}$ dan $\mathrm{P}$ pada kondisi media tanam tercemar hidrokarbon. Agrista 17(3): 119-126

Mayura E, Yudafis, Herwita I, Darwati I. 2016. Pengaruh pemberian air kelapa dan frekuensi pemberian terhadap pertumbuhan benih cengkeh. Bul Littro. 27(2):123-128.

Ratnawati, Saputra SI, Yoseva S. 2013. Waktu Perendaman Benih Dengan Air Kelapa Muda Terhadap Pertumbuhan Bibit Kakao (Theobroma cacao L.). https://media.neliti.com /media/publications/201097-waktuperendaman-benih-dengan-airkelapa.pdf.
Rover. 2006. Pengaruh Jarak Tanam dan Pemberian Air Kelapa Muda Terhadap Pertumbuhan dan Produksi Kedelai (Glycine max L. Merr) [Skripsi]. Pekanbaru [ID] : Universitas Islam Riau.

Sudjana B. 2014. Penggunaan azolla untuk pertanian berkelanjutan. Jurnal Ilmiah Solusi. 1(2):72-81.

Suryati D, Sampurno, Edison A. 2015. Uji beberapa konsentrasi pupuk cair azolla (Azolla pinnata) pada pertumbuhan bibit kelapa sawit (Elaeisguineensis Jacg.) di pembibitan utama. Jurnal Online mahasiswa Fakultas Pertanian. (2) $1: 1-13$.

Sutedjo M. 1990. Pupuk dan Cara Pemupukan. Jakarta: Rineka Cipta.

Wijaya. 2019. Pertumbuhan dan hasil kacang hijau (Phaseoll(2us radiatus $\mathrm{L}$.) dengan pemberian air kelapa. Agroteknologi Tropika Lembab. 1(2):100-105 